\title{
Small Scale Industries and Tribal Women of Jharkhand: A Sociological Analysis
}

Rashmi Gupta*

Research Scholar, University Department of Sociology, Ranchi University, Ranchi, Jharkhand, India

\author{
Article History \\ Received: 08.12.2020 \\ Accepted: 21.12 .2020 \\ Published: 24.12.2020 \\ Journal homepage: \\ https://www.easpublisher.com
}

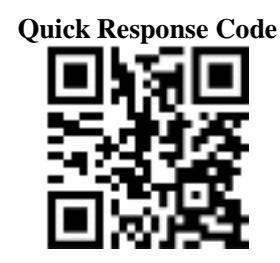

Abstract: The small scale industry sector has emerged over five decades as a highly vibrant and dynamic sector of the Indian economy. Today, this sector accounts for about 95 per cent of the industrial units and is contributing about 40 per cent of value addition in the manufacturing sector, nearly 80 per cent of manufacturing employment and about 35 per cent of exports both direct and indirect. Small scale industries are supplementing and complimentary to large and medium scale units as ancillary units. Considering to large employment level and backlog of creation of new jobs to provide employment to all able hands today hopes is pinned on the small scale sector. The Government is making all efforts to provide suitable atmosphere, level playing ground and policy support to enable the small scale industry sector to achieve higher levels of production, exports and employment. The Government of India has helped the tiny scale sector through supportive policy measures since adoption of planned economy model. Other policy supports which could be listed are excise exemption, credit under priority sector lending from banks and financial institutions, marketing support through reservation of items for products from small scale industry sector for state purchases, providing infrastructure facilities like sheds, plots in industrial estates, technological support, training and entrepreneurship development. In Jharkhand there is nearly 2 lac SSI working in different areas of the state. As the state is tribal dominating that's why most of the tribal people and specifically tribal women are working in these industries. They are mostly dependent for their livelihood on these kinds of industries. Through this paper I have tried to identify the impact of SSI on these tribal women in Jharkhand.

Keywords: SSI, Livelihood, Tribal, Women, Economic system, Social system.

Copyright @ 2020 The Author(s): This is an open-access article distributed under the terms of the Creative Commons Attribution 4.0 International License (CC BY-NC 4.0) which permits unrestricted use, distribution, and reproduction in any medium for non-commercial use provided the original author and source are credited.

\section{Small scale industries and tribal women of Jharkhand: A Sociological analysis \\ A small scale industry is an industrial} undertaking in which the investment under fixed assets in plant and machinery or equipment, whether held on ownership term or on lease or hire purchase, does not exceed ₹ 10 crore for manufacturing enterprise and ₹ 5 crore for service enterprise. However, the investment limit changes overtime as prescribed by the government. In accordance with the provision of Micro, Small \& Medium Enterprises Development (MSMED) Act, 2006 the Micro, Small and Medium Enterprises (MSME) are classified in two classes: 1. Manufacturing Enterprises: The enterprises engaged in the manufacturing or production of goods pertaining to any industry specified in the first schedule to the industries (Development and regulation) Act 1951 or employing plant and machinery in the process of value addition to the final product having a distinct name or character or use. The Manufacturing Enterprise is defined in terms of investment in Plant and Machinery. 2. Service Enterprises: The enterprises engaged in providing or rendering of services and are defined in terms of investment in equipment [1].

The limit for investment in plant and machinery/equipment for manufacturing /service enterprises is shown in Table I. 
Table-I: Limit for investment in plant and machinery / equipment

\begin{tabular}{|c|c|c|}
\hline \multirow[t]{2}{*}{ Enterprises } & \multicolumn{2}{|c|}{ Investment in plant and machinery / equipment } \\
\hline & Manufacturing Sector & Service Sector \\
\hline Micro & $<₹ 25$ lakh & <₹ 10 lalch \\
\hline Small & $>₹ 25$ lakb but $<₹ 5$ crore & $>$ ₹ 10 lalat but $<₹ 2$ crore \\
\hline Medium & $>₹ 5$ crore bat $<₹ 10$ crore & $>$ ₹ 2 crore but $<₹ 5$ crore \\
\hline
\end{tabular}

Industrial units are generally classified as small, medium and large scale units considering their size, capital invested and the number of human resource employed. The concept of small business has been defined by different countries in different ways; however the definition changes over time. The criteria adopted in different countries are shown in Table II.

Table-II: Criteria of defining small business in various countries

\begin{tabular}{|c|c|}
\hline Criterion & Countries \\
\hline Employment & USA and UK \\
\hline levestment in Plant and Machinery & India. Pakistan, Indoncsia \\
\hline Investment and Employment & Japan, Korca, Philippines \\
\hline Employ ment and Sales turnover & Korta(commero) \\
\hline Investrxent and Saks turnover & Malayila \\
\hline Production/ Saks turnover & China, UK(commercial) \\
\hline
\end{tabular}

\section{Small scale industries in India}

The SSI sector as an important segment of Indian economy, accounts for 95 per cent of the industrial units; 40 per cent of output in the manufacturing sector; employment to over 17 million persons; 35 per cent of total exports [2]. The SSI sector has been receiving due attention and importance from the policy makers owing to its special characteristics, namely, low level of investment required, high potential for creating employment opportunities, least location constraints, thereby contributing to a balanced regional development and a high utilization of local resources. This sector covers a wide spectrum of industries categorized under small, tiny and cottage segments. The sector has also maintained its pace of growth over the years, and has contributed significantly in supporting the overall economic development of the country.

\section{The following chart will show the different aspects of SSI in India}

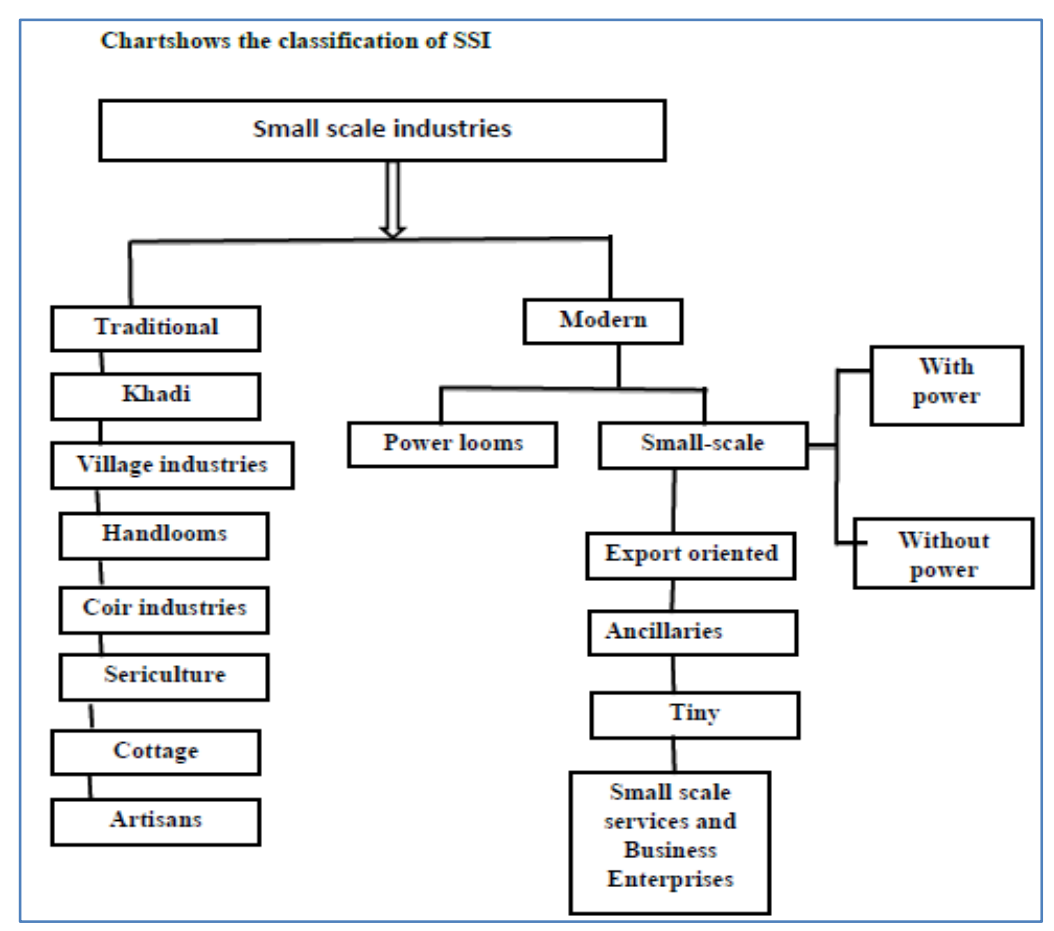


Small business has played a very crucial role in transforming the Indian economy from a backward agrarian economy to its present stature. Its benefits range from creating job opportunities for millions of people, including many with low levels of formal education. It has nurtured the inherent entrepreneurial spirit in far flung corners of the nation resulting in the growth and development of all regions. It has been instrumental in raising the standard of living of the multitudes. The small scale sector has contributed specifically in the following areas. The SSI sector in India is the second largest manpower employer in the country next only to the agriculture sector. India is characterized by abundant labour supply and is plagued by unemployment and underemployment. Under these circumstances the small-scale sector is a boon. For every Rs.0.1million of investment, the small-scale sector provides jobs to 26 people as compared to 4 jobs created in the large-scale sector [4].

It helps in industrialization of rural and backward areas. Many small units produce sub-parts, assemblies, components and accessories for the largescale sector especially in the electronic and automotive sectors. The most significant contribution of the SSI has been in the field of exports. There has been a significant increase in the exports from this sector of both traditional and non-traditional goods including jewellery, garments, leather, hand tools, engineering goods, software etc. Development of entrepreneurship is one of the major objectives of SSI ${ }^{\text {ee }}$. Small business taps the latent potential available locally. This way they facilitate the spirit of enterprise, which results in overall growth, and development of all the regions /sectors of the nation

\section{Small scale industries in Jharkhand}

MSME-Development Institute, Ranchi along with its Branch Institute at Dhanbad is catering to the development and promotional requirements of Micro Small\& Medium Enterprises (MSME) in the state of Jharkhand. The Jharkhand State was carved out of erstwhile Bihar. This 28th State came into existence on 15th November 2000. From administrative point of view Ranchi is the State Capital.

\section{'JHARKHAND INDUSTRIAL POLICY,} 2001 has been formulated. No alteration or changes have been introduced so far. Apex Committee has also been constituted to look into industrial sickness. To cater to the needs of sick units and to avoid further sickness of the industrial units, Jharkhand Rehabilitation Scheme, 2003 has also been launched. Even medium \& large industries are being taken proper care of by the Deptt. of Industries, Govt. of Jharkhand. To make the environment congenial for industrial development, efforts are being made to implement 'SINGLE WINDOW SCHEME', where the entire facility to launch an industrial enterprise will be dealt with under a single roof. The State Govt. in its JIP2001 has envisaged the concept of 'UDYOG BANDHU', who would be the coordinator of various Govt. departments to facilitate smooth, functioning of 'Single Window System [5]'. Facelifts are being undertaken at Industrial Estates/Areas all over the State to give boost to existing as well new units. If such efforts continue, there will be no reason why Jharkhand would not stand at par with other industrially developed states of the Nation.

As of March 2007, the number of SSI existing in Jharkhand was $1,63,220$ out of which 28468 were registered units and remaining $1,34,752$ were unregistered units. This is an improvement from the scenario in 2005-06: around 25,418 registered units provided employment to 90,561 persons and 1,30,019 un-registered units employed 2,36,926 persons. For comparison with $2004-05$ period. Thus in totality 1 , 55,437 small scale units provided an employment to 3 , 27,487 persons in 2005-06[6].

\section{Tribal women in Jharkhand}

Livelihood system of tribe is primarily dependent on combination of agriculture, hunting, forest goods and laboring. Due to very small holding and very low productivity of the most tribal land, Tribe eke out living by maintaining a diversified pattern of occupation; no single activity provides sufficient resource to entirely ensure their livelihood. Women actively participate in agriculture and art and craft. Some significant works which are helpful for tribe livelihood are as follows:

Bamboo Brice-a- brac - Bamboo is blessing of nature for tribe. It is useful for their household as well as for commercial purpose. Tribal bamboo art is not only famous in Jharkhand but also all over India. They make basket from bamboo which is broadly used by non-tribal society. Comb, cot, tray, vase are also made by tribal. Usually men and women both engage in bamboo art. They go to nearby markets to sell selfmade bamboo items. On the other hand, they make their roof, door, carpet from bamboo. They chafe bamboo and make flute. Playing flute is a part of entertainment for tribal society. Children play flute during grazing cattle [7].

Rope making - Rope making is another commercial work for the tribe. Generally men engage in this work. Ropes are made from bark of trees and sabai grass. It is used to tie up cattle.

Plate making - Plate making is a very useful work for tribe. Plate making is done from leaf of Sal and Plash. Plates are used by non-tribal society in huge amount during wedding and shraadh ceremony. 
Stone art - Tribes make use full household utensil and also make sculpture for home decoration. They sell it nearby market, stone utensil and décore items are most demandable among non-tribal society.

Fishing - Fish is very special food of Jharkhand. Fishing is not only used by tribals for cooking but it gives commercial profit to tribals also. They use ancient technique for fishing like fishing-rod and worm. They make fishing rod themselves.

Hunting - Tribes use spear for hunting. They throw it from a distance with a force to kill animals. Tribes are very active trapper. Hunting is also facile livelihood recourse for tribals[8].

Farming - Farming is mainly single crop with paddy and vegetable cultivation but some time double cropping and third crop may be grown by tribal society. There is a greater reliance on paddy; vegetables which are cultivated nearly year round and overall food security extend from five to seven month. Most of the communities allow year round access for greater market orientation.

Ranching - Tribes love their cattle. Animal husbandry is a part of their life. They usually keep goat and sheep. Ranching is useful for getting meat, milk, skin, wool and dung. Tribes get more profit in ranching.

Weapons - Tribes make weapon from iron. Like gaff, arrow, axe. All iron weapons are used by tribes for their security and hunting. On the other hand, some iron items are used for farming and cooking work like bucket pan, stove etc. Tribal iron items are liked by non-tribal society so tribes sell their items too.

Honey collecting - Honey collecting is a very fruitful work for tribes. Generally man and women both are engaged in this work. They collect honey from natural process so they store their honey without refining. Women go to the market for selling honey. They use it as a medicine also.

Herbal medicine - Tribes have a very good knowledge about herbal plants, natural herb, medicine and herbage. They use medicated herbage for treatment of day to day illness. They sell their herb to the nearest villagers or in bazaar. Sometimes tribes use poison of snake, cowse urine to make medicine or massage oil. Tribals in particular, an economically weaker section of the community in general, have a special aptitude for pig rearing and it can play a vital role in raising the economic condition of landless agriculture labourers.

Lac and Tasar - Lac and tasar is very productive for tribes. Lac is a resinous secretion from an insect. Lac cultivation process is traditional and it is passed on from generation to generation. On the other hand, Tasar cultivation is agro climatically suitable in the Santhal pargnas and south Chotanagpur region where there are abundant Asanand Arjun trees. Through creation of more private grainages, creation of adequate cocoon marketing facilities and setting up of reeling centers." Although Lac and Tasar are financially more beneficial for tribal societies but due to no proper presence of marketing and developing technique tribal couldn ${ }^{\text {ee }} \mathrm{t}$ get profit. If state protected tribes farming, Tasar and Lac can play an important role in tribese livelihood enhancement in Jharkhand.

Forest fruit gathering- Generally children and women engage in fruit and flower collecting from forest. Mahua is most conducive tree for tribes. Mahua is a typical fruit like a current. Tribal women collect Mahua early in the morning they make sweet bread from it and tribal men get juice from it and make wine. The tribes also pick raspberry, plum, custard apple, tamarind etc. Most tribal groups have been living in and around the forest for centuries, practicing fishing, hunting, fruit gathering and other activities, shifting cultivation, and some newly settled farming, as a main resource of subsistence. Generally farming is the chief source of livelihood for tribal community but agriculture has not given tribes the economic security. The main reasons include the small size of their farm holdings; low productivity, due to inefficient agricultural methods and lack of water for two crops; and the constant threat of wild animals (such as elephant $)^{\text {ee }}$. So they felt that farming is not sufficient for their subsistence so they started working as a paid labour, is helpful for the energy needs and some financial needs also. (N.A). Fuel wood supplies an average of 79 percent of energy needs. Fodder from the forest provides about 64 percent of the feed requirements for domestic live stock. Gross values were Rs 2,440 for fuel wood and Rs 10,992 for fodder per household per year." retroactively say that forest, land

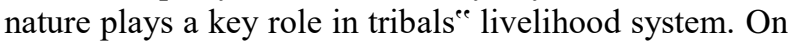
the other hand, tribal land alienation arose many troubles in tribal society. Tribal forest base livelihood system has shrunk. All the livelihood activities of tribal society visibly form a symbiotic relationship between tribes and nature. In 2007 the access of tribals to forests for their livelihoods has shrunk both because forests themselves have shrunk, and the regulatory regime continues to restrict tribals from collecting and processing non-timber forest produce for their livelihoods ${ }^{e e}$. Such tribal society have very actively deprived of their land rights by interferences of nontribes and government project or industry both. Apart from this, tribal households are receiving some cash fund and other type of help from several schemes like Mahatma Gandhi National rural Employment act. (MGNREGA), Swarna Jaynti Gram Swaraj Yojna (SGSY), Indira Awas Yojna, (IAY). All these schemes are provided by central government. Some under the 
state schemes are Jharkhand Economic survey (201314), Supply of uniforms to girl students belonging to STs/.., Bicycle Distribution scheme, Vocational training scheme for Pahariya primitive tribe, Lac Devolopment scheme for STs, Ayurvedic Health center scheme for the STs, Chief Minister"s Special Food Security Scheme for Primitive Tribe Groups. " State and center both provide development plans for tribes. They also try to make better plans for rural development too. Apart from this, it has been found that there is anarchy for local level governance, so tribal group couldn ${ }^{\text {ee }} \mathrm{get}$ benefit. Indeed as yet tribal women work in minimum living wage. Prakash [10]. They are less literate than men." which closes avenuesis helpful for the energy needs and some financial needs also. (N.A). Fuel wood supplies an average of 79 percent of energy needs. Fodder from the forest provides about 64 percent of the feed requirements for domestic live stock. Gross values were Rs 2,440 for fuel wood and Rs 10,992 for fodder per household per year." Retroactively say that forest, land nature plays a key role in tribalse livelihood system.

The number of registered small scale industries is highly concentrated in Hazaribag, Giridih, Ranchi, East Singhbhum and Dhanbad [11]. The distribution of small scale industries in the districts of Jharkhand are as below:

\begin{tabular}{|c|c|c|}
\hline Districts & $\begin{array}{c}\text { Total Registered and } \\
\text { operational Units }\end{array}$ & $\begin{array}{l}\text { Investment } \\
\text { (In Rs lakh) }\end{array}$ \\
\hline Garhwa & 709 & 214.45 \\
\hline Palamu & 1070 & 508.81 \\
\hline Chatra & 336 & 105.31 \\
\hline Hazaribagh & 1548 & 4248.49 \\
\hline Kodarma & 589 & 384.22 \\
\hline Giridih & 2271 & 2158.02 \\
\hline Deoghar & 1896 & 1189.34 \\
\hline Godda & 761 & 448.21 \\
\hline Sahibganj & 517 & 211.29 \\
\hline Pakaur & 612 & 293.27 \\
\hline Dumka & 1000 & 125.86 \\
\hline Dhanbad & 2400 & 2542.17 \\
\hline Bokaro & 964 & 360.39 \\
\hline Ranchi & 5075 & 4154.43 \\
\hline Lohardaga & 309 & 109.81 \\
\hline Gumla & 625 & 406.09 \\
\hline $\begin{array}{l}\text { Pashchimi } \\
\text { Singhbhum }\end{array}$ & 2381 & 1297.79 \\
\hline Purbi Singhbhum & 3042 & 1974.41 \\
\hline Simdega & 53 & 48.49 \\
\hline Latehar & 108 & 97.91 \\
\hline Jamtara & 78 & 94.51 \\
\hline Sariakela & 278 & 378.77 \\
\hline
\end{tabular}

Ranchi, Pashchimi Singhbhum, Purbi Singhbhum, Dhanbad, Giridih have the maximum operational small scale industries which is one of the main source of income and employment. Simdega and Jamtara have the least number of registered and operational small scale units. In parallel with the small scale industries, after the formation of the state 82 large and medium large and medium scale industries have been into operation in various sectors of sponge iron, pig iron, TMT bars plant, cement, ferro alloy and auto components. These large and medium scale industries entailed an investment of Rs. 31, 05,559 lakh and have generated an employment to 6,893 people.

The upcoming ventures in various sectors of the state would create an employment for 16, 16,703 persons. Thereby the manpower requirement for skilled labour would be 30,005 with 5,390 at the managerial level and 24,615 with technical background. The upcoming ventures would also provide employment to the around 2, 40, 830 unskilled laboures and indirect employment to 13, 44, 316 labourers [12]. 


\section{Employment by different Industry category}

\begin{tabular}{|l|c|c|}
\hline \multicolumn{1}{|c|}{ Industry Categories } & \multicolumn{2}{c|}{2005} \\
\cline { 2 - 3 } & $\begin{array}{l}\text { Public } \\
\text { Sector }\end{array}$ & $\begin{array}{l}\text { Private } \\
\text { Sector }\end{array}$ \\
\hline 1. Agriculture, Hunting, Forestry & 7.03 & 0.64 \\
\hline 2. Fishing & 0.15 & NA \\
\hline 3.Mining \& Quarrying & 507.58 & 21.08 \\
\hline 4. Manufacturing & 125.22 & 99.09 \\
\hline 5.Electricity, Gas\& Water Supply & 15.6 & 0.17 \\
\hline 6. Construction & 27.85 & 6.37 \\
\hline $\begin{array}{l}\text { 7. Wholesale\& Retail \&Repair of } \\
\text { Motor Cycles }\end{array}$ & 0.94 & 3.93 \\
\hline 8. Hotels \& Restaurants & 0 & 1.25 \\
\hline $\begin{array}{l}\text { 9. Transport, Storage \& } \\
\text { Communication Services }\end{array}$ & 59.23 & 1.28 \\
\hline 10. Financial Intermediaries & 14.46 & 0.22 \\
\hline $\begin{array}{l}\text { 11. Real Estate, Renting \& Business } \\
\text { Activity }\end{array}$ & 15.55 & 2.92 \\
\hline 12. Public Administration \& Defence & 49.88 & NA \\
\hline 13. Education & 46.04 & 10.76 \\
\hline 14 Health \& Social Work & 13.51 & 1.62 \\
\hline $\begin{array}{l}\text { 15. Other Community Social \& } \\
\text { Personal Service Activities }\end{array}$ & 8.65 & 1.01 \\
\hline $\begin{array}{l}\text { 16.Private Households with employed } \\
\text { persons }\end{array}$ & NA & NA \\
\hline $\begin{array}{l}\text { 17. Extra Territorial Bodies \& } \\
\text { Organizations }\end{array}$ & NA & NA \\
\hline Total & 891.68 & 1042 \\
\hline
\end{tabular}

As tribal women are being considered as the backbone of their family and society and also they do participate at equal level on gender basis. Tribal women are keenly interested and actively participating in economic activities. Small scale industry has been accorded an important place in their economic life by the familial and societal decision makers. As Small units generate employment at relatively small capital cost, mobilize resources of capital and skill at micro levels and are expected to meet the rising demand for various goods and services required by the economy. Small scale industry fomis an important sector constituting nearly 40 percent of the Total output in the private sector. That's why most of the tribal women are getting employment opportunities and earning money for their familial survival. Small scale sector are as a priority sector of the tribal economy is protected and promoted in a number of ways. Women continued to play a significant role. Collection of minor forest produce is done mostly by women and children. Many also work as laborers in industries, households and construction, contributing to their family income. Despite exploitation by contractors and managers, tribals are more sincere and honest than non tribals. However, tribal women face problems and challenges in getting a sustainable livelihood and a decent life due to environmental degradation and the interference of outsiders [13]. The strategy for tribal development, and specially women, needs improvement, betterment, development and upliftment to effect their empowerment. Tribal women have adjusted themselves to live a traditional life style in the local environment and follow occupations based on natural resources. Undoubtedly, the programmes, oriented towards the empowerment of tribals, particularly women, have improved their socio-economic conditions and status.

For striking balanced development of the economy of the tribal women, SSIs constitute an indispensable part of planned strategy. In agro-based activities, the participation rate of tribal women is much more than what statistics reveal. The reason behind this is that most of the farming and household activities done by the women are treated as daily chores. In this day and age, with the growing problem of unemployment, SSIs seems to be the appropriate solution to the problem among tribal women. It helps in employment generation for a number of people. This is particularly more beneficial for tribal women as it helps them to simultaneously carry out their household as well as livestock activities. They have the privilege of having sufficient resources to embark on SSIs ventures. For instance, they have easy access to farm and livestock based raw materials and other resources. Hence, tribal women can effectively undertake both the production and processing based activities. SSIs development plays a significant role in aiding the tribal women to enhance their personal capabilities and increase decision-making status in the family and society as a whole making them a pivotal part of the system. SSIs in rural area are the solution to these challenges. SSIs not only help in the enhancement of 
national productivity, employment generation but also in developing economic independence, personal and social capabilities among tribal women. Economic empowerment of women by SSIs has resulted in the empowerment of tribal women in various aspects such as socio-economic opportunity, property rights, political representation, social equality, family development, community development and finally the development of the nation. With their effective involvement in SSIs activities, the achievement of tribal women can be huge. Tribal women have basic indigenous knowledge, skills, potential and resources to set up and run the SSIs. SSIs network helps the tribal women in providing the requisite technical knowledge in production, processing, procurement, management and marketing. This move would definitely become a motivating factor for tribal women to engage in SSIs thereby adding to the family income and national productivity.

\section{CONCLUSION}

Tribal Women face many obstacles, specifically in marketing their product (including family responsibilities), that have to be overcome in order to give them access to the same opportunities as men. The entry of rural women in small scale industries must be encouraged and aggravated. Rural women can do wonders by their effectual and competent involvement in small scale activities. The rural women have the basic indigenous knowledge, skill, potential and resources to establish and manage small scale industries. Now, the need is for knowledge regarding accessibility to loans, various funding agencies, procedures regarding certification, awareness on government welfare programmes, motivation, technical skill and support from family government and another organisation. Moreover, formation and strengthening of rural women SSIs network must be encouraged. The banking institutions must offer formalised credit facility this sector must be included in the registered sector category by the government to promote women development among rural women. This support will help the women to strengthen their family bonds through financing themselves, and thus help in the economic growth. This article highlights the importance and need of the rural women SSI workers, to be included in the government's registered sector which would pave the way for economic development of the country. Thus, it can be asserted that tribal women can perform better, both in urban and rural areas, given that the government provides them financial support by including them under the registered sector as in SSIs.

\section{REFERENCES}

1. The gazette of India, S.O. 1642(E) dated. 29-092006 Development Commissioner (MSME) Govt. Of. India

2. Gupta, C.B., \& Khanka, S.S. (2010). 'Entrepreneurship and Small Business Management', Sultan Chand \& Sons, New Delhi, 2.4

3. SIDBI. (1999). Report on Small Scale Industries, 18

4. Ibid Gupta and Khanka, 2003; 5-6

5. www.jharkhandindustry.gov.in

6. www.jharkhandindustries.com

7. Berger, P., \& Heidemann, F. (Eds.). (2013). The modern anthropology of India: ethnography, themes and theory. Routledge.

8. Burman, B. R. (2003). Indigenous and tribal peoples in world system perspective. Studies of Tribes and Tribals, 1(1), 7-27.

9. Bijoy, C.R. (2007). Adivasi of India A history of disorientation, conflict and resistance This is our home land, pp-16 Retrieved at http//www.googlebook.com

10. Prakash, A. (2007). pp- 21, 34, 43 retrieved http:// www.unredd.net

11. Jharkhand Economic survey. (2013-14). Executive summary, 12, Retrieved http:// http://financejharkhand.gov.in

12. www.indiastats.com and Ministry of Labour \& Employment, Govt. of India

13. Malik, K., \& Sah. (2005). Socio economic upliftment of tribal communities in Jharkhand through agro forestay based farming system, 3 . 